\title{
Study of Correlation between Clinical Diagnosis by Syndromic Approach and Aetiological Laboratory Diagnosis amongst Women with Vaginal Discharge due to Candidial Vulvo-vaginitis and Bacterial Vaginosis Presenting to Gynecology OPD
}

\author{
Dr. Kalpana Kathrotiya ${ }^{1}$, Dr. Amisha Gheewala ${ }^{2}$, Dr. Ragini Verma ${ }^{3}$
}

Government Medical College, Surat, India

\begin{abstract}
Aims: To study Correlation between clinical diagnosis by Syndromic approach and etiological laboratory diagnosis. Setting and Design: This observational study was carried out at Gynecology OPD in tertiary care hospital in Gujarat, India. Material and Mathods: Total of 500 consenting subjects diagnosed as infective vaginal discharge based on syndromic approach were recruited for study. Their clinical profile was noted and they were investigated for Bacterial vaginosis and Vulvo vaginal candidiasis.
\end{abstract}

Keywords: bacterial vaginosis and vulvovaginal candidiasis

\section{Introduction}

Vaginitis is a common disease that affects women health with over $50 \%$ of the women experiencing at least one episode of vaginal infection in their lifetime.It occurs in 1$14 \%$ of all women in the reproductive age group and is responsible for 5-10 million OPD visits per year throughout the world. The prevalence of vaginal discharge in India is estimated to be $30 \%$.Infectious vaginitis is most commonly grouped in three major categories of the disease based upon microbial aetiology: Bacterial vaginosis, Vaginal Candidiasis and Vaginal Trichomoniasis. Because these three infectious syndromes are caused by different group of microorganisms, accurate and reliable diagnosis is necessary to initiate appropriate treatment.

Successful management of symptomatic vaginal discharge lies in the diagnostic approach. The traditional approach to diagnosis is through laboratory diagnosis of the etiological agents. This approach is expensive and not available at all health centres or dispensaries. Most of the times a presumptive diagnosis is made on the nature of discharge, which is often inaccurate and incomplete. $(6,7)$.

The present study was conducted to determine the accuracy of visual/presumptive diagnosis of symptomatic vaginal discharge and to evaluate if addition of simple microscopic technique such as Gram's stain can aid in the accurate diagnosis of this common condition. This study also tries to evaluate the accuracy of blanket therapy advocated by WHO in the syndromic management of Vaginal discharge.

Inclusion criteria:

- Consenting women with clinical evidence of infective vaginal discharge.

Exclusion criteria:

- Women with vaginal discharge of non-infective origin.
- Women with clinical evidence of infective vaginal discharge who did not give consent for enrolment in the study.

- Pregnant women with infective Vaginal discharge.

- Known HIV positive women with vaginal discharge

\begin{tabular}{|c|c|c|}
\hline Characteristic & $\begin{array}{c}\text { Number of subjects } \\
(n=500)\end{array}$ & Percentage \\
\hline \multicolumn{3}{|c|}{ Age } \\
\hline$<20$ years & 29 & $5.8 \%$ \\
\hline $20-25$ years & 150 & $30 \%$ \\
\hline$>25$ years & 321 & $64.2 \%$ \\
\hline \multicolumn{3}{|c|}{ Socio Economic Status } \\
\hline Lower & 451 & $90.2 \%$ \\
\hline Middle & 41 & $8.2 \%$ \\
\hline Upper & 08 & $1.6 \%$ \\
\hline \multicolumn{3}{|c|}{ Marital status } \\
\hline Married & 480 & $96 \%$ \\
\hline Unmarried & 20 & $4 \%$ \\
\hline \multicolumn{3}{|c|}{ Obstetric History } \\
\hline Nullipara / Para 1 & 130 & $26 \%$ \\
\hline Para 2 & 170 & $34 \%$ \\
\hline$\geq$ Para 3 & 200 & $40 \%$ \\
\hline \multicolumn{3}{|c|}{ Presenting Complaints } \\
\hline Pruritis vulva & 149 & $29.8 \%$ \\
\hline Dysuria & 133 & $26.6 \%$ \\
\hline Dyspareunia & 34 & $6.8 \%$ \\
\hline Lower abdominal pain & 48 & $9.6 \%$ \\
\hline \multicolumn{3}{|c|}{ Treatment for similar complaints in last six months } \\
\hline Yes & 157 & $31.4 \%$ \\
\hline No & 343 & $68.6 \%$ \\
\hline \multicolumn{3}{|c|}{ Consistent use of barriers in last six month } \\
\hline Yes & 138 & $27.6 \%$ \\
\hline No & 362 & $72.4 \%$ \\
\hline \multicolumn{3}{|c|}{ Associated Diabetes mellitus } \\
\hline Yes & 36 & $7.2 \%$ \\
\hline No & 464 & $92.8 \%$ \\
\hline
\end{tabular}




\section{International Journal of Science and Research (IJSR) \\ ISSN (Online): 2319-7064}

Index Copernicus Value (2013): 6.14 | Impact Factor (2015): 6.391

- Majority of our subjects are more than 25 year old,belong to low socio economical status, married and are multipara.

- The commonest associated complaint noted in my subjects was pruritis vulva which was seen in $29.8 \%$ subjects, followed by dysuria in $26.6 \%$ subjects.

- $31.4 \%$ subjects had taken treatment for similar complaints in the previous six months suggesting improper or incomplete treatment taken previously or re-infection.

Our observations (examination findings), clinical diagnosis and lab diagnosis results are presented below in Table 2

Table 2

\begin{tabular}{|c|c|c|}
\hline & $\begin{array}{l}\text { Number of } \\
\text { subjects } \\
(n=500)\end{array}$ & Percentage \\
\hline \multicolumn{3}{|c|}{ Examinations findings } \\
\hline Lower abdominal tenderness & 41 & $8.20 \%$ \\
\hline \multicolumn{3}{|l|}{ Per speculum findings } \\
\hline Curdy white discharge & 145 & $29 \%$ \\
\hline Frothy green discharge & 15 & $3 \%$ \\
\hline Greyish discharge & 240 & $48 \%$ \\
\hline Mucopurulent discharge & 100 & $20 \%$ \\
\hline \multicolumn{3}{|c|}{ Clinical diagnosis } \\
\hline Trichomonas vaginitis & 15 & $3 \%$ \\
\hline Vulvovaginal candidiasis & 145 & $29 \%$ \\
\hline Bacterial vaginosis & 240 & $48 \%$ \\
\hline Cervicitis & 100 & $20 \%$ \\
\hline \multicolumn{3}{|c|}{ Laboratory findings } \\
\hline \multicolumn{3}{|l|}{ Serological results $(n=500)$ : } \\
\hline RPR positive & 10 & $2 \%$ \\
\hline HIV positive & 27 & $5.4 \%$ \\
\hline Nugent score $(n=132)$ & & \\
\hline $0-3$ & 9 & \\
\hline $4-6$ & 35 & \\
\hline $7-10$ & 88 & \\
\hline Candidiasis $(\mathrm{n}=500)$ & 96 & $38 \%$ \\
\hline
\end{tabular}

Table 2 reveals that lower abdominal tenderness was noted in $8.2 \%$ subjects.

- Greyish discharge was commonest and seen in $48 \%$ subjects

- Curdy white discharge adherent to the lateral vaginal wall was seen in $29 \%$ subjects,

- Mucopurulent cervical discharge in $20 \%$ subjects,

- frothy green discharge was seen in 3\% subjects.

Based on the symptoms and clinical examination findings the distribution of diagnosis was as follows:

- Bacterial vaginosis $48 \%$ (commonest)

- Trichomonal vaginitis in $3 \%$

- Cervicitis in $20 \%$

- Vulvovaginal candidiasis in $29 \%$ subje

Result of clinical diagnosis as per syndromic approach to the lab diagnosis as is presented in table 3 below:
Table 3

\begin{tabular}{|c|c|c|c|}
\hline \multirow{2}{*}{$\begin{array}{c}\text { Clinical } \\
\text { diagnosis as } \\
\text { per syndromic } \\
\text { approach } \\
\text { guidelines }\end{array}$} & $\begin{array}{c}\text { Correlates } \\
\text { with } \\
\text { clinical } \\
\text { diagnosis }\end{array}$ & $\begin{array}{c}\text { Does not } \\
\text { correlate with } \\
\text { clinical } \\
\text { diagnosis }\end{array}$ & Total \\
\hline VVC & 96 & 49 & 145 \\
\hline BV & 88 & 152 & 240 \\
\hline Total & 184 & 201 & 385 \\
\hline
\end{tabular}

- Of the 385 subjects with VVC $(n=145)$ and BV $(n=240)$; lab diagnosis correlated in $184(47.79 \%)$ and it did not correlate in $201(52.20 \%)$ subjects.

- Correlation with lab diagnosis was seen in 96 out of 145 in VVC $(66.2 \%)$ and in 88 of 240 subjects with BV (36.66\%).. The follow-up visit results are as follows:

Table 4

\begin{tabular}{|c|c|c|c|}
\hline Clinical diagnosis & $\begin{array}{c}\text { Available } \\
\text { for follow } \\
\text { up }\end{array}$ & $\begin{array}{c}\text { Improvement } \\
\text { in symptoms }\end{array}$ & $\begin{array}{c}\text { No } \\
\text { improvement } \\
\text { in symptoms }\end{array}$ \\
\hline BV $(\mathrm{n}=240)$ & 200 & 180 & 20 \\
\hline VVC $(\mathrm{n}=145)$ & 140 & 108 & 32 \\
\hline TV $(\mathrm{n}=15)$ & 15 & 13 & 02 \\
\hline Cervicitis $(\mathrm{n}=100)$ & 98 & 83 & 15 \\
\hline Total $(500)$ & 453 & 384 & 69 \\
\hline
\end{tabular}

- Of the 500 subjects, $453(90.6 \%)$ presented for follow up at 14 days after initial visit.

- A total of 384 out of these 453 (84.76\%) subjects reported improvement in symptoms, while 69 of $453(15.23 \%)$ did not have any improvement in symptoms.

Relief in symptoms was noted in 180 of $200(90 \%)$ of BV cases, 108 of $140(77.14 \%)$ of VVC cases, 13 of 15 TV cases $(86.66 \%)$ and 83 of the $98(84.69 \%)$ cervicitis subjects who turned up after 14 days.

\section{Conclusion}

In my study laboratory correlation with clinical diagnosis based on Syndromic Approach from the "National technical Guidelines for treatment to RTI/STI September 2014” was seen in $47.79 \%$ subjects only. But $84.76 \%$ subjects managed as per the national guidelines responded to the therapy.

Considering the satisfactory response rate to therapy based on syndromic approach it can be said that syndromic approach to RTI/ STI is practical option for management of vaginal discharge considering the expense and delay involved in a etiological diagnosis.

\section{References}

[1] National technical Guidelines for treatment to RTI/STI September 2014"

[2] Toppo M, Tiwari SC, Dixit GC Nandeshwar. Study of STD pattern in Hamida hospital, Bhopal and its associated risk factors.Indian $\mathrm{J}$ community Med 2004;29:65-6.

[3] Thulkar, J., Kriplani, A., Aggrwal, N.,Vishnuhatla, S., Indian J Med Res 2010, 131,83-87. 


\section{International Journal of Science and Research (IJSR) \\ ISSN (Online): 2319-7064}

Index Copernicus Value (2013): 6.14 | Impact Factor (2015): 6.391

[4] French, L., Horton, J., Matousek, M., The Journel Of Medical Practice 2004,53.805- 814.

[5] Ryan, C.A., Zidouh, A., Manhart, L.E., Selka, R., Xia, M., Maloney-Kittis,M. et al, Sex Transum Infect 1998,74,895-105.

[6] Vishwanath, S., Talwar, V., Prasad, R., , Sex Transum Infect 2000,786,303-306.

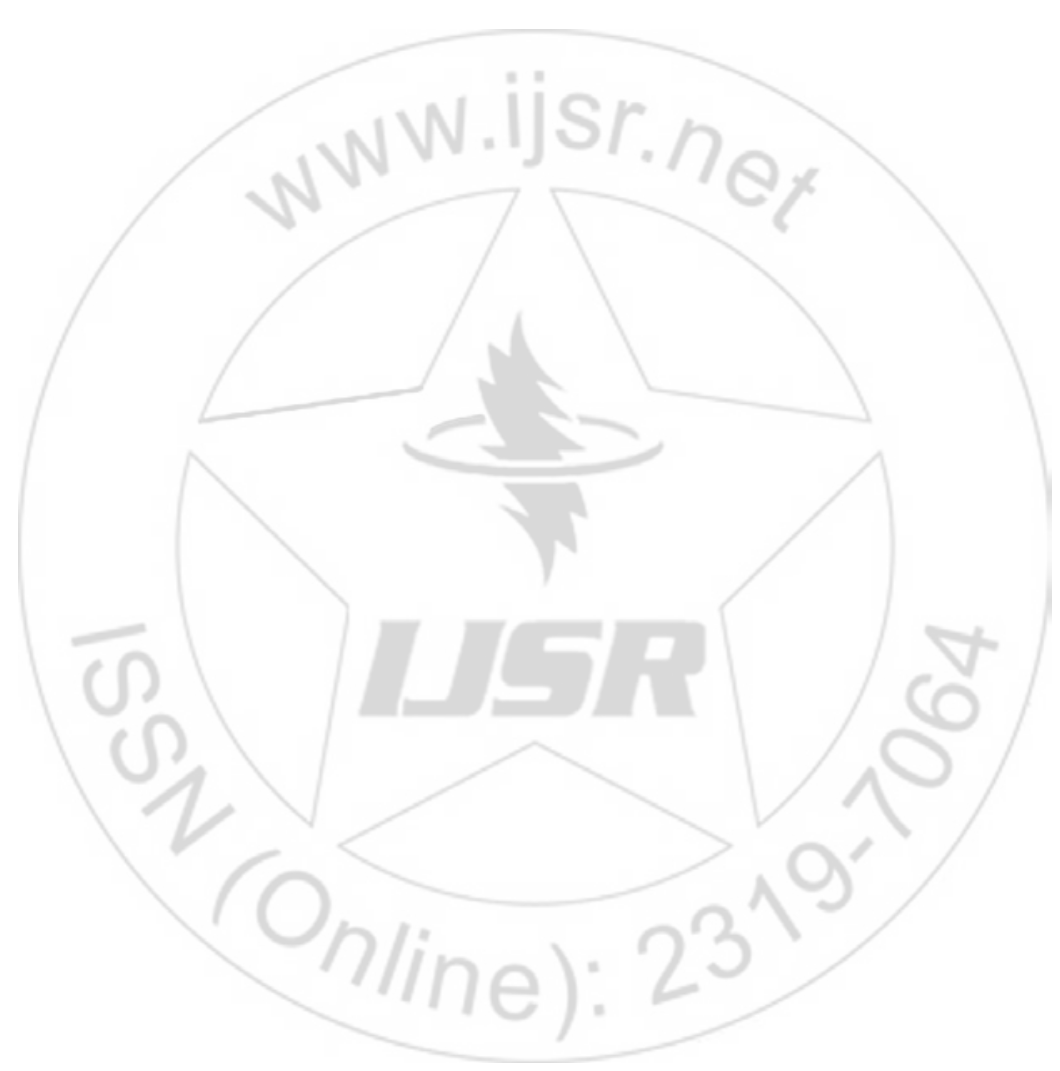

Volume 5 Issue 5, May 2016 www.ijsr.net 